\title{
The effects of low level laser therapy on
} the management of chronic idiopathic orofacial pain: trigeminal neuralgia, temporomandibular disorders and burning mouth syndrome

\section{Učinak mekog lasera u liječenju kroničnih idiopatskih bolova orofacijalne regije: trigeminalne neuralgije, temporomandibularnih poremećaja i sindroma pekućih usta}

\author{
Robert Antonić ${ }^{1}$, Martina Brumini ${ }^{2}$, Ivana Vidović ${ }^{2}$, Miranda Muhvić Urek ${ }^{3}$, Irena Glažar ${ }^{3}$, \\ Sonja Pezelj-Ribarić3
}

\begin{abstract}
Aim: To investigate the efficacy of different wavelengths of low level laser therapy (LLLT) in the management of orofacial pain by measuring the pain reduction using visual analogue scale (VAS). Materials and methods: Study involved 20 patients with trigeminal neuralgia (TN), 20 with temporomandibular disorders (TMD) and 40 with burning mouth syndrome (BMS). $50 \%$ of the patients in each syndrome group were treated with $660 \mathrm{~nm}$ laser, and other $50 \%$ with $810 \mathrm{~nm}$ laser. Orofacial pain was quantified by the VAS. Results: VAS was significantly lower after the application of LLLT, in all subjects and for both applied wavelengths $(P<0.05)$. Efficacy of $810 \mathrm{~nm}$ laser compared to $660 \mathrm{~nm}$ laser was significantly higher for all patients and in both the TN and TMD groups $(P<0.001 ; P=0.005 ; P=0.024)$. Conclusions: LLLT has proven to be an effective intervention in reducing pain in TN, TMD and BMS patients. Better results can be achieved with higher wavelengths.
\end{abstract}

Key words: burning mouth syndrome; facial pain; lasers; pain measurement; temporomandibular joint disorders; trigeminal neuralgia

\begin{abstract}
Sažetak. Cilj: Ispitati učinke različitih valnih duljina mekog lasera (ML) u liječenju orofacijalnog bola mjerenjem prijavljenog bola na vizualno-analognoj skali (VAS). Materijali i metode: U istraživanju je sudjelovalo 20 ispitanika s trigeminalnom neuralgijom (TN), $20 \mathrm{~s}$ temporomandibularnim poremećajima (TMP) i 40 sa sindromom pekućih usta (SPU). $50 \%$ ispitanika u svakoj skupini liječeno je laserom $660 \mathrm{~nm}$, a preostalih $50 \%$ laserom $810 \mathrm{~nm}$. Orofacijalni bol određen je prema VAS-u. Rezultati: Nakon primjene ML-a prijavljeni bol bio je značajno manji za sve ispitanike $(P<0,05)$. Značajno veće smanjenje bola ostvareno je primjenom lasera $810 \mathrm{~nm}$ za sve pacijente te za TN i TMP grupu $(P<0,001 ; P=0,005 ; P=$ $0,024)$. Zaključci: ML pokazao se učinkovitom metodom smanjenja bola kod TN-a, TMP-a i SPU-a. Bolji rezultati ostvaruju se primjenom veće valne duljine.
\end{abstract}

Ključne riječi: bol lica; laseri; mjerenje bola; poremećaji temporomandibularnog zgloba; sindrom pekućih usta; trigeminalna neuralgija
${ }^{1}$ Department of Prosthodontics, Faculty of Medicine, University of Rijeka, Rijeka

${ }^{2}$ Department of Endodontics, Faculty of Medicine, University of Rijeka, Rijeka

${ }^{3}$ Department of Oral Medicine and Periodontology, Faculty of Medicine, University of Rijeka, Rijeka

\author{
*Corresponding author: \\ Martina Brumini, DMD \\ Department of Endodontics \\ Faculty of Medicine, University of Rijeka \\ Braće Branchetta 20, 51000 Rijeka \\ e-mail: martina.brumini@gmail.com
}




\section{INTRODUCTION}

Chronic idiopathic pain management is a growing challenge for both primary care physicians and specialists $^{1}$. In the orofacial region, the most common forms of chronic idiopathic pain are trigeminal neuralgia (TN), temporomandibular joint disorders (TMD) and burning mouth syndrome (BMS). In recent papers discussing the management of chronic idiopathic orofacial pain, authors state that it is crucial to have a multidi-

A great number of patients suffering from chronic idiopathic orofacial pain are not satisfied with medical therapy because of incomplete control of pain or drug-related side effects. Surgical treatment is often invasive and its results depend on many variables. Unsatisfactory therapeutic results necessitates finding alternative treatment.

mensional approach which includes pain specialists, headache neurologists, neurosurgeons, oral surgeons, liaison psychiatrists, physiotherapists, clinical psychologists and radiologists ${ }^{2,3}$. According to Zakrzewska, a combination of antidepressants and cognitive behaviour therapy gives the best results in the management of chronic idiopathic orofacial pain ${ }^{3}$. Although medication is often the first line of treatment, tolerance may develop as the treatment period and the need for extra dosage increase, which leads to more side effects. A great number of patients suffering from chronic idiopathic orofacial pain are not satisfied with medical therapy because of incomplete control of pain or drug-related side effects $^{4,5}$. When drug therapy fails to control the pain, surgical treatment is usually proposed, especially in cases of TN pain 5 . Surgical treatment is often invasive and its results depend on many variables: experience, expertise and correct selection of technique of neurosurgery team. Unsatisfactory therapeutic, whether medicinal or surgical results necessitates finding alternative treatment.

Low level laser therapy (LLLT) uses low-powered laser light in the range of $1-1000 \mathrm{~mW}$, at wavelengths from $632-1064 \mathrm{~nm}$, to stimulate a biolog- ical response. These lasers emit no heat, sound, or vibration and act by inducing a photochemical reaction in the cell, a process referred to as biostimulation or photobiomodulation ${ }^{6}$. Its basic effects are biostimulative, regenerative, analgesic and antiinflammatory ${ }^{7}$. Laboratory studies suggest that irradiation stimulates collagen production, alters DNA synthesis, and improves the function of damaged neurological tissue. It is a treatment modality that is becoming widely known because it is a noninvasive, quick, safe nonpharmaceutical intervention ${ }^{8}$.

The aim of this study was to investigate the efficacy of different wavelengths of laser irradiation in the management of orofacial pain by measuring the pain reduction using visual analogue scale (VAS).

\section{MATERIALS AND METHODS}

The study protocol has been approved by the Ethical Committee of the Medical Faculty, University of Rijeka and Clinical Hospital Centre Rijeka. All subjects were informed of the aims and procedures of research, as well as the fact that their medical data would be used in research. Only those subjects who gave written permission in the form of informed consent were included.

\section{Participants}

The study involved 80 patients with diagnosed chronic idiopathic orofacial pain syndrome: 20 of them with TN, 20 with TMD and 40 with BMS. Patients were examined at the Oral Medicine Unit and Prosthetic Dentistry Unit, Clinical Hospital Centre Rijeka, Faculty of Medicine, University of Rijeka. The criteria for inclusion in the study were: diagnosis of chronic idiopathic orofacial pain syndrome, absence of any systemic diseases that might be involved, absence of any local oral factors that might be involved, orofacial pain during the last 14 days, no other therapy one month before and during the study. The diagnosis for TMD was made through a standard comprehensive clinical examination based upon the Research Diagnostic Criteria for Temporomandibular Disorders (RDC/TMD) 9 . The study included subjects suffering from myofascial pain with/without limited mouth opening. Classical TN was diag- 
nosed according to the International Classification of Headache Disorders Criteria ${ }^{10}$ and the duration of illness ranged from 6 to 12 months. The criteria for inclusion in the BMS group was: BMS diagnosis and the absence of any systemic diseases or local oral factors that might be involved in the sensation of mouth burning. The individuals underwent complementary examinations (complete blood count, blood glucose level and estrogen level) and only those with normal values took part in the study. After medical, dental and social histories of each participant were collected, clinical examination was performed according to the standard clinical criteria. Each patient was evaluated according to subjective pain reporting: 0-10 VAS. Orofacial pain was quantified by the VAS, where 0 inidicated "no pain" and 10 indicated "the worst possible pain" 6 .

\section{Methods}

Research was conducted during 2014. The patients were treated with LLLT 5 days per week for 4 consecutive weeks with a $660 \mathrm{~nm}$ or $810 \mathrm{~nm}$ Ga-Al-As (Gallium-Aluminum-Arsenide) diode laser (Medio LASER Combi Dental, Iskra Medical, Ljubljana, Slovenia). In each syndrome-group, $50 \%$ of the participants were treated with $660 \mathrm{~nm}$ laser and $50 \%$ of them with $810 \mathrm{~nm}$ laser: 10 participants of TN group, 10 participants of TMD group and 20 participants of BMS group were treated with $660 \mathrm{~nm}$ laser; and 10 participants of TN group, 10 participants of TMD group and 20 participants of BMS group were treated with $810 \mathrm{~nm}$ laser. During each session, the laser light was delivered to the tissue by a straight optical fiber with a $2 \mathrm{~mm}$ spot size and the output power was measured at the fiber aperture. The laser output power was monitored weekly using analogue power meters provided by the manufacturer. The output power of the laser was measured for $7 \mathrm{~min}$ and found to be practically constant. The treatment areas, each one being a $1 \mathrm{~cm}^{2}$ surface were used on tender points diagnosed at the start of the treatment. The laser was applied for approximately 10 minutes (810 nm or $660 \mathrm{~nm}$, continuous wave, $30 \mathrm{~mW}$ output power, $\left.3.0 \mathrm{~J} / \mathrm{cm}^{2}\right)$. The treatment time $(\mathrm{t})$ for each application point was calculated using the following equation ${ }^{11}$ :

$$
t(\mathrm{sec})=3.0 \frac{\mathrm{J}}{\mathrm{cm}^{2}} \times 1 \frac{\mathrm{cm}^{2}}{0.003}(\mathrm{~W})
$$

The effect of the laser light was evaluated after the final treatment.

\section{Statistical analysis}

Statistical analyisis of the data was performed using Statistica 10.10 (StatSoft Inc., Tulsa, SAD). The normal distribution of age was checked by Kolmogorov-Smirnov test. Data of age were presented as median and $\left(5^{\text {th }}-95^{\text {th }}\right)$ percentile boundaries,

LLLT stimulates collagen production and improves the function of damaged neurological tissue. Better results can be achieved with higher wavelenghts. It is also important for reducing coasts of treatment, as we have less need for surgical treatment or medicine use. Because only 6-10 applications are necessary to achieve pain relief, LLLT may also have a positive psychological effect.

minimum and maximum. Differences in age between participants were checked using KruskalWallis test. The analysis of the presence gender was performed using $\chi^{2}$ test. Data of VAS were presented as median and $\left(5^{\text {th }}-95^{\text {th }}\right)$ percentile boundaries. Results of VAS before and after LLLT were compared using the Wilcoxon test. Statistical analysis of VAS before and after LLLT at each wavelength was performed using Mann-Whitney test. All statistical values were considered significant at $P=0.05$.

\section{RESULTS}

Demographic characteristics of all participants are shown in Table 1. There was no significant difference between groups regarding the age of the patients $(P=0.149)$. There were significantly more female than male patients $(P=0.007)$. In the BMS group there were significantly more female than male patients $(P=0.004)$.

In all 3 groups, for both $660 \mathrm{~nm}$ and $810 \mathrm{~nm}$ applied wavelength, VAS after LLLT was significantly lower than before LLLT. In all 3 groups, $810 \mathrm{~nm}$ laser showed better results assessed through VAS reduction. Efficacy of $810 \mathrm{~nm}$ laser compared to $660 \mathrm{~nm}$ laser was significantly higher in TN group and in TMD group ( $P=0.005$ and $P=0.024)$; (Table 2 ). 
Table 1. Demographic characteristics of participants

\begin{tabular}{|c|c|c|c|c|c|}
\hline & $\begin{array}{l}\text { Trigeminal } \\
\text { neuralgia }\end{array}$ & $\begin{array}{l}\text { Temporomandibular } \\
\text { disorders }\end{array}$ & $\begin{array}{l}\text { Burning mouth } \\
\text { syndrome }\end{array}$ & All & $P$ \\
\hline $\mathrm{N}$ & 20 & 20 & 40 & 80 & \\
\hline \multirow{2}{*}{ Age* / years (min-max) } & $53(32-71.5)$ & $44.5(28-60)$ & $51(29.5-75.5)$ & $50(28.5-72)$ & 0.149 \\
\hline & $27-72$ & $27-63$ & $25-80$ & $25-80$ & \\
\hline Male / n (\%) & $12(60)$ & $9(45)$ & $9(22.5)$ & $30(30.7)$ & \\
\hline Female / n (\%) & $8(40)$ & $11(55)$ & $31(77.5)$ & $50(62.5)$ & \\
\hline$P$ & 0.392 & 0.662 & 0.004 & 0.007 & \\
\hline
\end{tabular}

*data are presented as median $\left(5^{\text {th }}-95^{\text {th }}\right)$ percentile boundaries, minimum and maximum

Table 2. Efficacy of different wavelenghts assessed through VAS reduction

\begin{tabular}{|c|c|c|c|c|c|}
\hline Orofacial pain syndrome & $\mathbf{N}$ & $\begin{array}{c}\text { Laser wavelenght } \\
(\mathrm{nm})\end{array}$ & VAS before* & VAS after* & $P$ \\
\hline \multirow{3}{*}{ Trigeminal neuralgia } & 10 & 660 & $7(2-9)$ & $6.5(2-8)$ & 0.043 \\
\hline & 10 & 810 & $7(5-10)$ & $4(1-5)$ & 0.005 \\
\hline & & & 0.940 & 0.005 & \\
\hline \multirow{3}{*}{ Temporomandibular disorders } & 10 & 660 & $6.5(3-10)$ & $6(2-9)$ & 0.018 \\
\hline & 10 & 810 & $7(4-10)$ & $3(1-8)$ & 0.005 \\
\hline & & & 0.762 & 0.024 & \\
\hline \multirow{3}{*}{ Burning mouth syndrome } & 20 & 660 & $7(2-9.5)$ & $4.5(1-8)$ & 0.001 \\
\hline & 20 & 810 & $6(3.5-9)$ & $4(1-6.5)$ & $<0.001$ \\
\hline & & & 0.508 & 0.460 & \\
\hline \multirow{2}{*}{ All } & 40 & 660 & $7(2-9.5)$ & $5.5(1-8)$ & $<0.001$ \\
\hline & 40 & 810 & $6(4-10)$ & $3.5(1-6.5)$ & $<0.001$ \\
\hline All & 80 & & 0.736 & $<0.001$ & \\
\hline
\end{tabular}

*data are presented as median $\left(5^{\text {th }}-95^{\text {th }}\right)$ percentile boundaries

\section{DISCUSSION}

Results of this study showed that subjective pain, measured using VAS, after the use of LLLT was significantly lower in patients with TN, TMD and BMS, for both $660 \mathrm{~nm}$ and $810 \mathrm{~nm}$ lasers. By performing searches on Medline database using: LLLT, TN, TMD and BMS as keywords non of the research was found. Therefore, we concluded that this was the first research that investigated different wavelenghts of LLLT in the treatment of TN, TMD and BMS.

One of the studies on the use of LLLT in the management of different disorders of orofacial region, performed by Pinheiro et al. showed reduction of pain in TMD, TN, inflammation, tooth hypersensitivity and aphtae after the application of LLLT. Authors suggested that the reduction of pain in TMD patients may be due to an increased release of $\beta$-endorphins, whereas the reduction of pain in TN patients may be a result of a recovery of the neuronal activity and function $^{12}$.

A majority of the studies on the use of LLLT in the management of chronic idiopathic orofacial pain involved TMD. Statistically significant reduction of pain in the laser group in relation to the placebo was observed in research by Gray et al. ${ }^{13}$, Bertolucci and Grey ${ }^{14}$, Fikácková et al. ${ }^{15}$, Mazzetto et al. ${ }^{16}$, Öz S et al. ${ }^{17}$, Çetiner et al. ${ }^{18}$ and Venezian et al. ${ }^{19}$. Some of the studies reported both reduction of pain as well as a significant improvement in the range of mandibular movements and decreased tenderness of masticatory muscles ${ }^{20-22}$.

Previous studies suggest that both idiopathic TN and idiopathic BMS may be of neuropathic origin. Several authors suggested that pathogenesis of TN may involve axon and myelin changes ${ }^{23,24}$. Tongue biopsies in BMS patients showed a significant reduction of epithelial nerve fibres versus 
control group ${ }^{25,26}$. The treatment of neuropathic pain conditions often involves a variety of medicines with many side effects and, as the treatment continues, the need for extra dosage increase ${ }^{27,28}$. Medicinal management often includes antidepressants but, as studied by Tammialia-Salonen et al. antidepressants did not effectively relieve BMS associated symptoms ${ }^{29}$. Effectiveness of LLLT in peripheral nerve regeneration was demonstrated in several studies ${ }^{30-32}$. Nerve regeneration and acceleration of axonal growth was observed in rats after the application of $780 \mathrm{~nm}$ laser $^{30}$. In another study, rabbits who were treated with $901 \mathrm{~nm}$ laser showed thicker nerve fibers, clearer Ranvier nodes and more regular myelin layers, compared to control group ${ }^{31}$. In a study by Romeo et al. $68 \%$ of BMS patients reported significant relief after LLLT $^{32}$. Statistically significant reduction in the salivary levels of proinflammatory cytokines TNF- $\alpha$ and IL- 6 was observed after the application of LLLT in BMS patients ${ }^{27}$. In the treatment of TN, LLLT has proven effective in several studies ${ }^{33-35}$. Vernon and Hasbun reported no pain after 12 sessions $^{35}$ and a study by Eckerdal and Bastian proved LLLT efficacy at one-year follow up ${ }^{34}$. Taken together, these results indicate that LLLT biostimulative effects may play an important role in the management of neuropathic pain conditions, such as idiopathic TN and idiopathic BMS.

In all 3 groups, greater VAS reduction was observed after the application of $810 \mathrm{~nm}$ laser compared to $660 \mathrm{~nm}$ laser. In a study by Carvalho et al., it was observed that greater laser wavelength was associated with greater pain reduction ${ }^{36}$. Previous research showed that the effectiveness of LLLT is greater when used in the spectrum of 780 to $904 \mathrm{~nm}$ because of increased penetration. Greater laser photobiomodulation is linked to higher irradiation protocols as well as to a greater number of sessions and frequency of application $^{37,38}$.

In some of the studies, LLLT did not show as effective in the management of orofacial pain conditions $^{39,40}$. López-Ramírez et al. used $810 \mathrm{~nm}$ laser to treat pain, facial swelling and trismus after surgical removal of impacted lower third mo$\operatorname{lar}^{39}$. We suppose the reason why LLLT did not show as effective is because it was appliaed in 1 session only. Research by León et al. showed that 6-10 applications were necessary to achieve pain relief in TMD patients ${ }^{41}$. Carrasco et al. reported less TMD symptoms and greater masticatory efficiency after $8^{\text {th }}$ laser session ${ }^{42}$. In another study, Amanat et al. aimed to evaluate the efficacy of LLLT in the treatment of TN, myofascial pain dysfunction syndrome and atypical facial pain ${ }^{40}$. Authors reported no significant differences between laser group and control group, and suggested there is no significant efficacy for LLLT in the management of orofacial pain conditions.

We assume the reason why LLLT failed to show its efficiency is because all patients received pharmaceutical treatment as well. This adds support for the hypothesis that pain reduction from LLLT is achieved through an antiinflammatory action. Kim et al. reported greater pain relief in TN patients treated with LLLT alone compared to TN patients treated with a combination of LLLT and medications ${ }^{43}$. In previous mentioned study, León et al. compared LLLT to drug therapy in TMD patients. LLLT group showed better results assessed through $\mathrm{VAS}^{41}$.

\section{CONCLUSIONS}

LLLT with its biostimulatory, antiinflammatory and analgesic effects has proven to be an effective intervention in reducing pain in TN, TMD and BMS patients. Nevertheless, LLLT still has not been included in every day dental practice in the treatment of chronic idiopathic orofacial pain. One of the reasons might be a lack of standardization of treatment protocol for LLLT. Therefore, one of the aims of this paper was to contribute in developing specific guidelines for the use of LLLT in patients with TN, TMD and BMS. Our research suggests that better results can be achieved with higher wavelenghts. LLLT might also be important for reducing coasts of treatment, as we have less need for surgical treatment or medicine use. Because only 6-10 applications are necessary to achieve pain relief, LLLT may also have a positive psychological effect, especially on patients suffering from chronic pain conditions, such as TN, TMD and BMS.

Conflicts of interest statement: The authors report no conflicts of interest. 


\section{REFERENCES}

1. Verhaak PF, Kerssens JJ, Dekker J, Sorbi MJ, Bensing JM. Prevalence of chronic benign pain disorder among adults: a review of the literature. Pain 1998;77:231-9.

2. Hals EKB, Stubhaug A. Mental and somatic co-morbidities in chronic orofacial pain conditions: Pain patients in need of multiprofessional team approach. Scandinavian J Pain 2011;2:153-4.

3. Zakrzewska JM. Multi-dimensionality of chronic pain of the oral cavity and face. J Headache Pain 2013;14:37.

4. Cheshire WPJ, Wharen REJ. Trigeminal neuralgia in a patient with spontaneous intracranial hypotension. Headache 2009;49:770-3.

5. Cheshire WP. Trigeminal neuralgia: diagnosis and treatment. Curr Neurol Neurosci Rep 2005;5:79-85.

6. Aimbire F, Albertini R, Pacheco MT, Castro-Faria-Neto $\mathrm{HC}$, Leonardo PS, Iversen VV et al. Low-level laser therapy induces dose-dependent reduction of TNF-alpha levels in acute inflammation. Photomed Laser Surg 2006; 24:33-7.

7. Beckerman H, de Bie RA, Bouter LM, De Cuyper HJ, Oostendrop RAB. The efficacy of laser for musculoskeletal and skin disorders: a criteria - based meta-analysis of randomized clinical trials. Phys Ther 1992;72:13-21.

8. Simunovic-Soskic M, Pezelj-Ribaric S, Brumini G, Glazar I, Grzic R, Miletic I. Salivary levels of TNF- $\alpha$ and IL- 6 in patients with denture stomatitis before and after laser phototherapy. Photomed Laser Surg 2010;28:189-93.

9. Dworkin SF, LeResche L. Research diagnostic criteria for temporomandibular disorders: review, criteria, examinations and specifications, critique. J Craniomandib Disord 1992;6:301-55.

10. Headache Classification Committee of the International Headache Society (IHS). The International Classification of Headache Disorders, $3^{\text {rd }}$ Edition (beta version). Cephalalgia 2013;33:775-6.

11. Pascu ML. Laser physics elements to consider for low level laser therapy. Laser therapy 2011;13:114-25.

12. Pinheiro ALB, Cavalcanti ET, Pinheiro TITNR, Alves MJPC, Manzi CTA. Low-level laser therapy in the management of disorders of the maxillofacial region. J Clin Laser Med Sur 1997;15:181-3.

13. Gray RJM, Quayle AA, Hall CA, Schofield MA. Physiotherapy in the treatment of temporomandibular joint disorders: a comparative study of four treatment methods. Br Dent J 1994;176:257-61.

14. Bertolucci LE, Gray T. Clinical analysis of midlaser versus placebo treatment of arthralgic TMJ degenerative joints. Cranio 1995;13:26-9.

15. Fikácková H, Dostálová T, Navrátil L, Klaschka J. Effectiveness of low-level laser therapy in temporomandibular joint disorders: a placebo-controlled study. Photomed Laser Surg 2007;25:297-303.

16. Mazzetto MO, Carrasco TG, Bidinelo EF, Pizzo RCA, Mazzettp RG. Low intensity laser application in temporomandibular disorders: a phase I double-blind study. Cranio 2007;25:186-92.

17. Lassemi E, Jafari SM, Motamedi MHK, Navi F, Lasemi R. Low level laser therapy in the management of temporamandibular joint disorder. J Oral Laser Applications 2008;8:83-6.
18. Çetiner S, Kahraman SA, Yücetas S. Evaluation of low-level laser therapy in the treatment of temporomandibular disorders. Photomed Laser Surg 2006;24:637-41.

19. Venezian GC, Silva MA, Mazzetto RG, Mazzetto MO. Low level laser effects on pain to palpation and electromyographic activity in TMD patients: a double-blind, randomized, placebo-controlled study. Cranio 2010; 28:84-91.

20. Mazzetto MO, Hotta TH, Pizzo RC. Measurements of jaw movements and TMJ pain intensity in patients treated with GaAlAs laser. Braz Dent J 2010;21:356-60.

21. Dostalová T, Hlinakova P, Kasparova M, Rehacek A, Vavrickova L, Navrátil L. Effectiveness of physiotherapy and GaAlAs laser in the manegement of temporomandibular joint disorders. Photomed Laser Surg 2012;30: 275-80.

22. Azizi A, Sahebjamee M, Lawaf S, Jamalee F, Maroofi N. Effects of low-level laser in the treatment of myofascial pain dysfunction syndrome. J Dent Res Dent Clin Dent Prospects 2007;1:53-8.

23. Jainkittivong A, Aneksuk V, Langlais RP. Trigeminal neuralgia: a retrospective study of 188 Thai cases. Gerodontology 2012;29:611-7.

24. Siddiqui MN, Siddiqui SS, Ranasinghe JS, Furgang FA. Pain management: trigeminal neuralgia. Hospital Physician 2003;39:64-70.

25. Suarez P, Clark GT. Burning mouth syndrome an update on diagnosis and treatment methods. J Calif Dent Assoc 2006;34:611-22.

26. Lauria G, Maiorana A, Borgna M, Lombardi M, Penza P, Padovani $A$ et al. Trigeminal small-fiber sensory neuropathy causes burning mouth syndrome. Pain 2005; 115:332-7.

27. Pezelj-Ribarić S, Kqiku L, Brumini G, Urek MM, Antonić $\mathrm{R}$, Kuiš $\mathrm{D}$ et al. Proinflammatory cytokine levels in saliva in patients with burning mouth syndrome before and after treatment with low-level laser therapy. Lasers Med Sci 2013;28:297-301.

28. Falaki F, Nejat AH, Dalirsani Z. The effect of low-level laser therapy on trigeminal neuralgia: a review of literature. J Dent Res Dent Clin Dent Prospects 2014;8:1-5.

29. Tammiala-Salonen T, Forssell H. Trazodone in burning mouth pain: a placebo-controlled, double-blind study. J Orofac Pain 1999;13:83-8.

30. Rochkind S, Leider-Trejo L, Nissan M, Shamir RH, Kharenko O, Alon M. Efficacy of 780-nm laser phototherapy on peripheral nerve regeneration after neurotube reconstruction procedure (double-blind randomized study). Photomed Las Surg 2007;25:137-43.

31. Ihsan FR, Al-Mustawfi N, Kaka LN. Promotion of regenerative processes in injured peripheral nerve induced by low level laser therapy. Photomed Las Surg 2007; 25:107-11.

32. Romeo U, Del Vecchio A, Capocci M, Maggiore C, Ripari $M$. The low level laser therapy in the management of neurological burning mouth syndrome. A pilot study. Ann Stomatol 2010;1:14-8.

33. Walker J, Akhanjee L, Cooney M, Goldstein J, Tamayoshi $\mathrm{S}$, Segal-Gidan F. Laser therapy for pain of trigeminal neuralgia. Clin J Pain 1988;3:183-7.

34. Eckerdal A, Bastian H. Can low reactive-level laser therapy be used in the treatment of neurogenic facial pain? A double-blind, placebo controlled investigation of pa- 
tients with trigeminal neuralgia. Laser Therapy 1996;8: 247-52.

35. Vernon LF, Hasbun RJ. Low-level laser therapy for trigeminal neuralgia. Pract Pain Manag 2008;8:56-63.

36. Carvalho CM, Lacerda JA, Santos Neto FP, Cangussu MC, Marques AM, Pinheiro ALB. Wavelenght effect in temporomandibular joint pain: a clinical experience. Lasers Med Sci 2010;25:229-32.

37. Venancio R de A, Campari CM, Lizarelli R de F. Low intensity laser therapy in the treatment of temporomandibular disorders: a double-blind study. J Oral Rehabil 2005;32:800-7.

38. Maia ML, Bonjardim LR, Quintans Jde S, Ribeiro MA, Maia LG, Conti PC. Effect of low-level laser therapy on pain levels in patients with temporomandibular disorders: a systematic review. J Appl Oral Sci 2012;20:594-602.

39. López-Ramírez M, Vílchez-Pérez MA, Gargallo-Albiol J, Arnabat-Domínguez J, Gay-Escoda C. Efficacy of low- level laser therapy in the management of pain, facial swelling, and postoperative trismus after a lower third molar extraction. A preliminary study. Lasers Med Sci 2012;27:559-66.

40. Amanat $D$, Ebrahimi H, Lavaee F, Alipour A. The adjunct therapeutic effect of lasers with medication in the management of orofacial pain: double blind randomized controlled trial. Photomed Laser Surg 2013;31:474-9.

41. León IG, Almagro S, García RC. Los trastornos temporomandibulares y la radiación láser. Rev-Cubana Estomatol 2007;44:1-8.

42. Carrasco TG, Mazzetto MO, Mazzetto RG, Mestriner W, Jr. Low intensity laser therapy in temporomandibular disorder: a phase II double-blind study. Cranio 2008;26: 274-81.

43. Kim HK, Jung JH, Kim CH, Kwon JY, Baik SW. The effect of lower level laser therapy on trigeminal neuralgia. J Korean Pain Soc 2003;16:37-41. 